Jurnal Mandala Pharmacon Indonesia, Vol 5.No.1 Juni 2019

Avaiable online at www.jurnal-pharmaconmw.com/jmpi

p-ISSN : 2442-6032

$e$-ISSN : 2598-9979

\title{
Pengaruh Pola Makan Terhadap Potensi Resiko Penyakit Diabetes Melitus
}

\author{
${ }^{1}$ Arikha Ayu Susilowati, ${ }^{2}$ Kuncara Nata Waskita \\ 1Program Studi S1 Farmasi,STIKES Bhakti Husada Mulia \\ ${ }_{2}^{2}$ Program Studi D3 Farmasi, STIKES Bhakti Husada Mulia
}

\begin{abstract}
ABSTRAK
Gaya hidup masyarakat saat ini mengalami banyak perubahan, baik yang dilakukan oleh remaja maupun dewasa. Makanan cepat saji dan instan merupakan jenis makanan yang paling banyak digemari, Konsumsi banyak makanan yang mengandung gula akan menyebabkan berbagai penyakit, salah satunya diabetes melitus. Untuk menjaga kadar gula darah, jadwal makan dan porsi makan perlu di atur. Mengurangi porsi makan dapat membantu mengontrol gula darah, sedangkan menambah porsi makan dapat menimbulkan komplikasi Diabetes Melitus. Oleh karena itu perlu adanya suatu penelitian untuk mengetahui pengaruh pola makan remaja terhadap apotensi resiko penyakit diabetes mellitus. Jenis penelitian ini menggunakan

meliputi jenis kelamin, umur, pendidikan dan olahraga juga dihubungkan dengan resiko penyakit diabetes mellitus. Data yang dianalisis adalah pola makan manis, pola makan asin dan pola makan berlemak yang dihubungkan dengan pengaruh resiko penyakit diabetes melitus. Signifikansi faktor yang menghubungkan kejadian diabetes melitus adalah jenis kelamin, umur dan pola makan. Pola konsumsi makanan asin berisiko 2,62 kali terkena diabetes melitus. Sedangkan pola konsumsi makanan manis dan berlemak berisiko lebih rendah terkena diabetes melitus. Jadi pengaruh resiko penyakit Diabetes Mellitus pada remaja tidak berpengaruh, tetapi sebaiknya remaja tetap menjaga pola makan yang baik dan sehat sedini mungkin.
\end{abstract} analitik korelatif dan menggunakan pendekatan cross sectional. Penelitian ini menjelaskan tentang hubungan antara variabel jenis, jumlah, dan jadwal makan dengan kadar gula darah pasien DM. Pendekatan cross sectional mengumpulkan variabel dependent dan variabel independent dalam waktu yang bersamaan dan secara langsung. Data dianalisis menggunakan uji one way annova. Deskripsi responden yang
Kata kunci : Gaya Hidup, Pola Makan, Diabetes Mellitus.

\section{Penulis korespondensi :}

Arikha Ayu Susilowati, Program Studi S1 Farmasi,STIKES Bhakti Husada Mulia

E-mail : arikhasains2017@gmail.com

\section{PENDAHULUAN}

Gaya hidup adalah bagian dari kebutuhan sekunder manusia yang bisa berubah bergantung zaman atau keinginan seseorang untuk mengubah gaya hidupnya. Gaya hidup manusia di zaman modern saat ini sudah banyak yang mengabaikan sisi kesehatan seperti pola makan yang tinggi lemak, garam, dan gula, serta cara hidup yang kurang sehat. Hal ini merupakan salah satu faktor utama berkembangnya jumlah penyakit degeneratif pada masyarakat. Salah satu contoh penyakit degenerative tersebut adalah Diabetes Melitus (yang selanjutnya disingkat DM).

Menurut Abdul Kadir (2016), kadar gula darah dapat di atur lebih stabil dengan cara mengatur jadwal makan yang teratur (makan pagi, makan siang, makan malam). Selain itu, mengatur 
porsi makan juga berpengaruh pada gula darah. Mengurangi porsi makan dapat membantu mengontrol gula darah, sedangkan menambah porsi makan dapat menimbulkan komplikasi Diabetes Melitus.

Perubahan gaya hidup masyarakat Indonesia saat ini berkiblat pada gaya hidup di barat. Hal tersebut mengakibatkan perubahan pola makan masyarakat merujuk pada pola makan tinggi kalori, tinggi lemak dan kolesterol terutama pada makanan siap saji (fast food) yang berdampak meningkatkan risiko obesitas. Dalam penelitian yang lain mengatakan bahwa perilaku olahraga atau aktivitas fisik yang kurang dari 2 kali seminggu mempunyai risiko 4,5 kali terkena diabetes mellitus tipe 2 dibandingkan mereka yang melakukan aktivitas fisik atau olahraga teratur (Fayasari, Julia dan Emy, 2018)

Uraian diatas melatar belakangi kami untuk melakukan penelitian tentang "Hubungan Pola Makan Dengan Penyakit Diabetes Melitus di Rumah Sakit Madiun”.

\section{METODE PENELITIAN}

\section{Desain Penelitian}

Jenis penelitian ini menggunakan analitik korelatif dan menggunakan pendekatan cross sectional. Penelitian ini menjelaskan tentang hubungan antara variabel jenis, jumlah, dan jadwal makan dengan kadar gula darah pasien DM. Pendekatan cross sectional mengumpulkan variabel dependent dan variabel independent dalam waktu yang bersamaan dan secara langsung. Data dianalisis menggunakan uji one way annova. Deskripsi responden yang meliputi jenis kelamin, umur, pendidikan dan olahraga juga dihubungkan dengan resiko penyakit diabetes mellitus. Data yang dianalisis adalah pola makan manis, pola makan asin dan pola makan berlemak yang dihubungkan dengan pengaruh resiko penyakit diabetes mellitus.

\section{Populasi dan Sampel}

Populasi

Populasi pada penelitian ini adalah pasien diabetes mellitus yang menjalani rawat jalan di rumah sakit di Madiun.

Sampel

Sampel dalam penelitian ini adalah pasien diabetes mellitus yang menjalani rawat jalan di RS di Madiun sejumlah 100 orang.

\section{Teknik Pengambilan Sampel}

Penelitian ini menggunakan teknik accidental sampling. Menurut Sugiyono (2004), accidental sampling adalah teknik penentuan sampel yang berdasarkan pada kebutuhan, yaitu sampel yang secara kebetulan bertemu dengan peneliti pada rentang penelitian.

\section{Waktu dan Tempat Penelitian}

Penelitian ini akan dilaksanakan pada bulan Juni 2017 di Rumah Sakit Madiun

\section{Definisi Operasional}

1. Jenis kelamin adalah perbedaan bentuk, sifat dan jenis makhluk hidup. Pada penelitian ini dikategorikan sebagai: laki-laki dan perempuan.

2. Pekerjaan adalah aktivitas mata pencaharian yang dimiliki oleh responden. Pada penelitian ini dikategorikan sebagai: bekerja dan tidak bekerja.

3. Pendidikan adalah pembelajaran pengetahuan, keterampilan dan ilmu seseorang. Pada penelitian ini dikategorikan sebagai: rendah dan tinggi.

4. IMT (indeks massa tubuh) adalah berhubungan status gizi responden yang didapatkan dari rumus: berat 
badan dibagi tinggi badan (dikuadratkan). Kemudian hasilnya dapat dikategorikan tidak normal jika $<18,5$ dan $\geq 23,0 \mathrm{~kg} / \mathrm{m}^{2}$.

5. Olahraga adalah suatu bentuk fisik yang terencana dan terstruktur yang melibatkan gerakan tubuh berulangulang dan ditujukan untuk meningkatkan kebugaran jasmani. Pada penelitian ini dikategorikan: ya dan tidak.

6. Makanan manis adalah jenis makanan yang mengandung gula, yang memiliki nutrisi rendah namun kalori tinggi. Pada penelitian ini dikategorikan: konsumsi dan tidak konsumsi.

7. Makanan asin merupakan jenis makanan yang memiliki kandungan garam tinggi. Pada penelitian ini dikategorikan: konsumsi dan tidak konsumsi.

8. Makanan berlemak merupakan jenis makanan yang memiliki kandungan lemak tinggi. Pada penelitian ini dikategorikan: konsumsi dan tidak konsumsi.

9. Kriteria Inklusi :

a. Pasien dewasa usia lebih dari 17 tahun

b. Pasien diabetes mellitus tanpa penyakit penyerta

c. Pasien yang menjalani rawat jalan di RS Madiun

10. Kriteria Eksklusi : a. Pasien diabetes mellitus dengan penyakit penyerta

b. Pasien yang tidak bersedia menjadi responden

\section{Prosedur Pengumpulan Data}

Pada penelitian ini, Proses pengumpulan data primer dan data sekunder dilakukan menggunakan kuisioner. Prosedur pengumpulan data dilakukan sebagai berikut:

a. Penjelasan terkait maksud dan tujuan penelitian kepada responden dan meminta persetujuan dengan mendatangi informed concent

b. Penjelasan mengenai tata cara pengisian kuesioner

c. Pencatatan hasil pengukuran pada formulir lembar penelitian

d. Pencatatan rekam medis pasien terkait tentang hasil laboratorium pemeriksaan gula darah 2 jam setelah makan.

\section{Analisis Data}

a. Data Univariat

Data Univariat dilakukan untuk menjelaskan gambaran jadwal, jumlah, jenis makan dan kadar gula darah.

b. Data Bivariat

Data bivariat digunakan untuk melihat apakah ada hubungan antara variabel independen (jumlah, jadwal, dan jenis makan) dengan variabel dependen (kadar gula darah). 


\section{HASIL DAN PEMBAHASAN}

Hasil dari penelitian ini dapat dilihat pada tabel 1

Tabel 1. Faktor Risiko Diabetes Melitus

\begin{tabular}{|c|c|c|c|c|}
\hline Variabel & Diabetes & Nondiabetes & OR & $95 \% \mathrm{CI}$ \\
\hline \multicolumn{5}{|c|}{ Karakteristik Responden } \\
\hline \multicolumn{5}{|l|}{ Jenis Kelamin } \\
\hline Laki & 22 & 12 & 2,48 & $1,06-5,86$ \\
\hline perempuan & 28 & 38 & 1 & \\
\hline \multicolumn{5}{|l|}{ Umur } \\
\hline$>50$ Tahun & 25 & 16 & 2,16 & $0,94-4,79$ \\
\hline$<50$ Tahun & 25 & 34 & 1 & \\
\hline \multicolumn{5}{|l|}{ Pekerjaan } \\
\hline Bekerja & 38 & 34 & 1,23 & $0,50-3,02$ \\
\hline Tidak bekerja & 12 & 14 & 1 & \\
\hline \multicolumn{5}{|l|}{ Pendidikan } \\
\hline Rendah & 26 & 17 & 2,10 & $0,21-1,55$ \\
\hline Tinggi & 24 & 33 & 1 & \\
\hline \multicolumn{5}{|l|}{ Indeks Massa tubuh } \\
\hline Tidak normal & 38 & 31 & 1,94 & $0,21-1,22$ \\
\hline Normal & 12 & 19 & 1 & \\
\hline \multicolumn{5}{|l|}{ Olah raga } \\
\hline Ya & 25 & 29 & 0,72 & $0,33-1,59$ \\
\hline Tidak & 25 & 21 & 1 & \\
\hline \multicolumn{5}{|l|}{ Makanan Manis } \\
\hline Konsumsi & 25 & 36 & 0,38 & $0,17-0,89$ \\
\hline Tidak konsumsi & 25 & 14 & 1 & \\
\hline \multicolumn{5}{|l|}{ Makanan asin } \\
\hline Konsumsi & 24 & 13 & 2,62 & $1,13-6,09$ \\
\hline Tidak konsumsi & 26 & 37 & 1 & \\
\hline \multicolumn{5}{|l|}{ Makanan berlemak } \\
\hline Konsumsi & 8 & 16 & 0,37 & $0,14-0,96$ \\
\hline Tidak konsumsi & 42 & 33 & 1 & \\
\hline
\end{tabular}

Faktor resiko diabetes berdasarkan dari berbagai karakteristik dapat dilihat pada tabel 1. Umur, jenis kelamin, , konsumsi makanan asin, makanan manis, dan makanan berlemak merupakan faktor-faktor yang signifikan ( $\mathrm{p}<0,05)$. Berdasarkan karakteristik jenis kelamin untuk laki-laki memiliki resiko 2,48 kali, pada usia diatas 50 tahun sebesar 2,16 kali, dan konsumsi makanan asin sebesar 2,62 kali terkena penyakit diabetes. Konsumsi makanan manis memiliki resiko 0,38 dan asin sebesar 0,37 . Hasil ini berbeda dengan penelitian witasari (2009) yang menunjukkan konsumsi makanan manis memiliki resiko diabetes melitus dua kali lipat.

- Berdasarkan karakteristik jenis kelamin dan umur. Laki-laki memeliki resiko yang lebih besar dibandingkan dengan perempuan yaitu 2,48 kali lebih beresiko. Penelitian juga menunjukkan bahwa jumlah penderita diabetes melitus adalah laki-laki dibanding perempuan. Faktor resiko diabetes adalah jenis kelamin, umur, obesitas, riwayat keluarga, aktifitas fisik, pola makan, dan merokok. Jenis kelamin dan umur adalah faktor yang tidak bisa dimodifikasi. Pada umur diatas 50 tahun, angka kejadian diabetes melitus meningkat sebesar 2,16 kali lebih tinggi. Meningkatnya umur akan berdampak pada penurunan fungsi dari organ tubuh salah satunya adalah kemampuan tubuh dalam memproduksi insulin sehingga mengganggu metabolisme glukosa (Nurwijayanti, 2018).

Faktor lain seperti pendidikan, pekerjaan, olah raga dan IMT tidak 
memberikan korelasi yang signifikan.. Hasil ini sejalan dengan dengan penelitian Trisnawati (2013) terhadap 100 responden pasien diabetes melitus yang melaporkan bahwa tidak adanya hubungan aktivitas fisik dengan keadaan kadar gula darah pasien diabetes melitus.

Konsumsi makanan berlemak dan manis memberikan hubungan yang signifikan dengan angka diabetes melitus. Penambahan minyak dan santan menjadi parameter dalam makanan berlemak. Minyak dan santan adalah makanan yang memiliki kadar lemak yang cukup tinggi. Persentase konsumsi responden pada makanan asin, berlemak, dan manis yaitu $48 \%, 16 \%$, dan $50 \%$. Persentase yang mengkonsumsi makanan asin dan manis hampir sama, sedangkan yang menkonsumsi lemak lebih kecil. Konsumsi makanan asin memiliki resiko sebesar 2,62 kali. 65\% responden dari seluruh responden yang mengkonsumsi makanan asin mendapatkan diabetes melitus. Natrium merupakan zat terbesar dalam makanan asin yang mengakibatkan retensi cairan dan menyebabkan hipertensi dan hipertensi adalah salah satu faktor resiko diabetes melitus. Pada responden sebesar $38 \%$ menderita hipertensi. Komplikasi yang umum pada penderita diabetes melitus adalah gangguan mata, penyakit kardiovaskular, gangguan saraf dan ginjal. Penyakit kardiovaskular merupakan penyebab tersbesar pengeluaran biaya pada penderita diabetes melitus. (Rahmawati dkk, 2014).

\section{KESIMPULAN}

Signifikansi

menghubungkan kejadian diabetes melitus adalah jenis kelamin, umur dan pola makan. Pola konsumsi makanan asin berisiko 2,62 kali terkena diabetes melitus. Sedangkan pola konsumsi makanan manis dan berlemak berisiko lebih rendah terkena diabetes melitus. Jadi pengaruh resiko penyakit Diabetes Mellitus pada remaja tidak berpengaruh, tetapi sebaiknya remaja tetap menjaga pola makan yang baik dan sehat sedini mungkin.

\section{UCAPAN TERIMA KASIH}

Terima kasih kepada pihak Rumah Sakit di wilayah Madiun yang telah mengijinkan melakukan penelitian ini.

\section{DAFTAR PUSTAKA}

Abdul Kadir, 2016. Kebiasaan Makan dan Gangguan Pola Makan Serta Pengaruhnya Terhadap Status Gizi Remaja. Jurnal Publikasi Pendidikan. Vol VI No 1. Pp 49-55

Fayasari, Julia dan Emy, 2018. Pola Makan dan Indikator Lemak Tubuh Pada Remaja. Jurnal Gizi Indonesia. Vol 7 No 1. Pp 15-21

Nurwijayanti, 2018. Pola Makan, Kebiasaaan Sarapan, dan Status Gizi Berhubungan Dengan Prestasi Belajar Siswa SMK di Kota Kediri. Vol 6 No 1. Pp 54-63

Rahmawati, Syam A, Hidayati. 2011. Pola makan dan aktivitas fisik dengan kadar glukosa darah penderita diabetes mellitus tipe 2 rawat jalan di RSUP Dr.Wahidin Sudiro husodo Makassar. Media Gizi Masyarakat Indonesia 1(1):52- 8.

Trisnawati S. 2013. Faktor risiko kejadian diabetes mellitus tipe II di Puskesmas Kecamatan Cengkareng Jakarta Barat Tahun 2012. Jurnal Ilmiah Kesehatan 5(1).

Witasari, U., Rahmawaty, S. and Zulaekah, S., 2009. Hubungan tingkat pengetahuan, asupan karbohidrat dan serat dengan pengendalian kadar glukosa darah pada penderita diabetes melitus tipe 2. 